\title{
Relation of Family Conditions and School Success
}

\author{
Vlasta Cabanová \\ University of Žilina, Žilina, Slovakia
}

\begin{abstract}
Each family has its own specifications and different volume of cultural capital which more or less stimulates the child development. Very specific is the case of book ownership in the family. The paper analyzes material and cultural environment of present-day families in the north-western part of Slovak republic. The author presents the results of observation of some material conditions in Slovak families with primary school children and finds out their impact on the children's school success.
\end{abstract}

Keywords: culture, material, and cultural conditions of families, ownership of books in the family, children's attitude to books, borrowing books in the public library, education of parents and borrowing books, school success

\section{Introduction}

It is undisputed that the culture of the family is determining in relation to society. In the education in the family, development of socio-affective aspect of child's personality, his culture is a priority: "The education of children to the culture is easier if parents themselves read books, visit theatres, museums, galleries and the like. They enrich their children's knowledge and enhance the education" (Makarenko, 1947). The condition of obtaining a relation to a book in the family resides in the presence, possibility of contact, handling and games with the book what causes a positive attitude to books (Šmelová, 2004) as soon as possible. "Considering pre-reading period, building a relation to the book lies especially in adults reading books, viewing folding picture-books, but child experimentation and various games with book toys are significant as well" (Cabanová, 2004).

\section{Theoretical Basis}

The Czech author J. Průcha (2004) belongs among the first experts in the field of education in Central Europe who characterized the family as a place where social inequalities are reproduced. A man is reflected in a family. Parents trying to pass on their life experience on children - "to pass craft" maintain existing condition. Tendency of parents to pass experience on "how to live", they contribute to maintain social inequalities, because workers educate workers and doctors (Katrňák, 2004).

In general, parents with higher education also have higher incomes and better material facilities in families and parents from lower classes do not have a volume of economic capital as parents with higher social status

\footnotetext{
* This paper has been written with the support of European Social Fund, project Innovation and Internationalization of Education - instruments to increase the quality of the University of Žilina in the European educational area (ITMS code 26110230079). Modern Education for the Knowledge Society/Project is funded by EU.

Vlasta Cabanová, associate professor, Department of Pedagogical Studies, Faculty of Humanities, University of Žilina.
} 
(Leláková \& Bačová, 2014). However, relationship between material environment of family and school performance of a child who grows up in this family is not direct, but is mediated by way of family life, parental attitudes to children and study (compliance with school duties), to the school. Neither the lack of economic capital directly affects the child's school performance, but rather indicates a specific lifestyle of family and specific definition of the world of parents and children who observe access to school and education (Katrňák, 2004).

\section{Implementation and Results of Research}

Department of Pedagogical Studies of University of Žilina, focused on the preparation of social educators, has been devoted to Slovak families and their specific problems in the northern part of Central Slovakia for years. It is also for this reason that its employees implemented the research in 2007 under the grant project VEGA 1-0737-8 called "socio-cultural context of family education in the Slovak regional transformations (especially Liptov rural) communities and community schools". They focused on the detection of socio-cultural conditions of families with school children, the analysis of these conditions and their relations to school performance of 7th and 8th class pupils of primary schools, while selectively focusing on the region of the lower Liptov.

There were involved 738 families (nearly 5,200 household members) in the research and within time interval of four years, we made a much smaller comparative research on sample of 240 families in 2014, and ultimately, a survey in the Žilina region as part of the final thesis under the author's leadership (Gabrišová, 2014). The aim of the research was to analyse the material and cultural conditions of families of the 7th and 8th class pupils, comparing the profit and material environment. In this paper, we focus on the findings in the context of a number of books in the families surveyed. We also wanted to find whether there are differences in the conditions of pupils in urban and rural schools in Slovakia. Due to the large scope of the data obtained, we present only some interesting findings.

\section{The Existence of Books in the Family}

In the first part of the research, we analysed the relation of children to books and their ownership. According to the findings (tool of questionnaire research), $87.95 \%$ of children had their own library. Most of the children of the total number stated that they had books at home in the range of 11 to 20 books which represents $28.92 \%$ and less than $18.07 \%$ stated they did not have their own books or more than five books. Therefore, we can conclude that most children had books at home in the range of six to 20 books. The next question was about what kind of books prevailed among children. Most of children of the total number who have their own books, almost half $(46.57 \%)$, stated that there was the same proportion of popular science literature and fiction in their own library. $28.77 \%$ of children had mostly non-fiction literature, dictionaries, and maps at home.

The existence, range and focus of the books constitute material and cultural environment of the family, but we were interested in what kind of relation children have to books and how often they read books. The question whether they liked reading books, $57.83 \%$ of children answered "Yes", which is a surprising result. We live in times when children lose interest in reading, so books are replaced by movies and the Internet. 
As to the children who responded that they liked reading books, we tried to find who had brought them to reading. The largest number of children stated that their own interest brought them in reading books-own initiative, which represents $39.58 \%$ of the number of children who like reading books. The other most frequent answer was mother and family members which does not surprise us, because the family environment is the first place where a child at an early age meets with a book. Only $14.58 \%$ of children stated the influence of teacher on the initiation of reading books.

After the popularity of reading books, we investigated how often children read books. Surprising result is that up to $36.14 \%$ of all children read books more times a week and $16.88 \%$ of the children several times a month. We found that $13.25 \%$ of all respondents did not read books at all. Figure 1 shows the percentage of the frequency of reading books.

\section{Reading and Ownership of E-books}

In addition to traditional forms of books, we currently notice the electronic books, so-called eBooks.

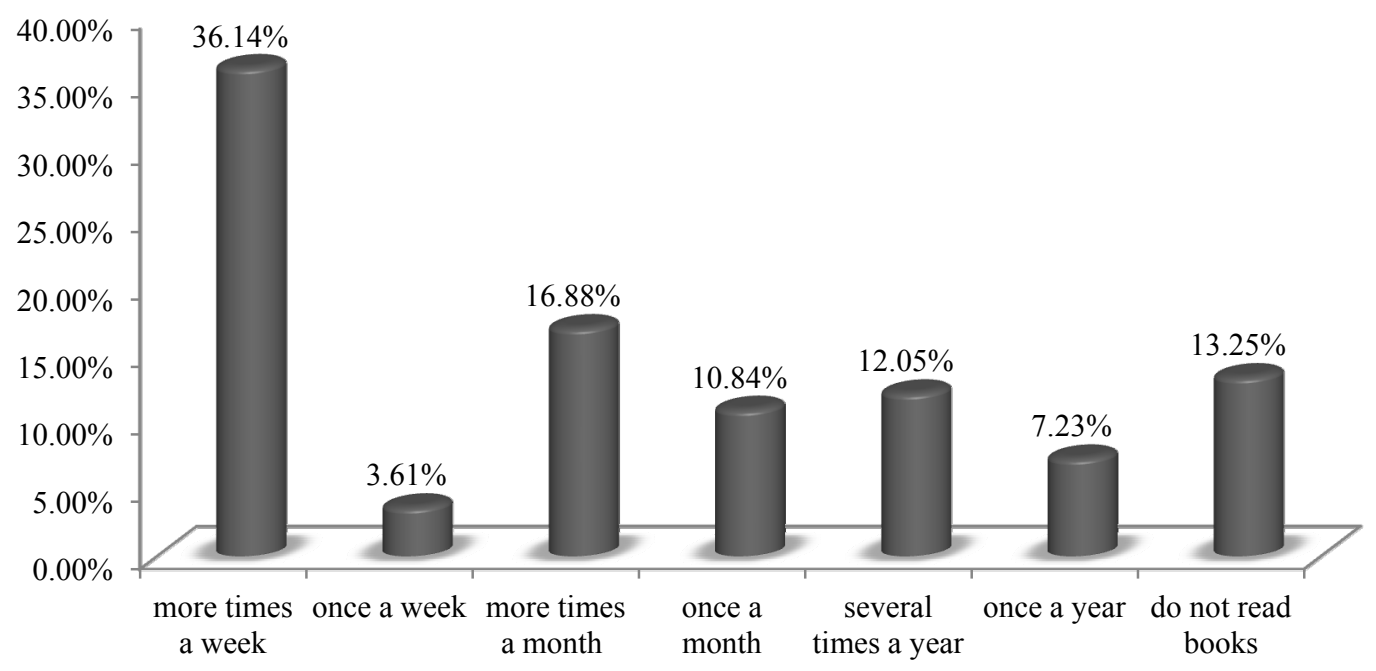

Figure 1. Frequency of reading books.

$60.24 \%$ of children did not meet with the eBook. We can say that children still attempt to reach the traditional form of book, $39.76 \%$ stated that they met with eBook and so we surveyed whether the children were from the city or the village. Only more than $3.04 \%$ of children from the city met with eBook compared to children from the village.

\section{Borrowing Books in Public (Municipal) Libraries}

Another interesting finding was that $92 \%$ of all respondents borrowed books from the library. Based on this result, we examined the kind of book range; there were $8 \%$ of children who did not borrow books from the library (see Figure 2).

Based on the results, we can claim that all children who had up to 10 books at home preferred borrowing from a public library. With the increasing number of books in private ownership, the visit of public library decreases. 


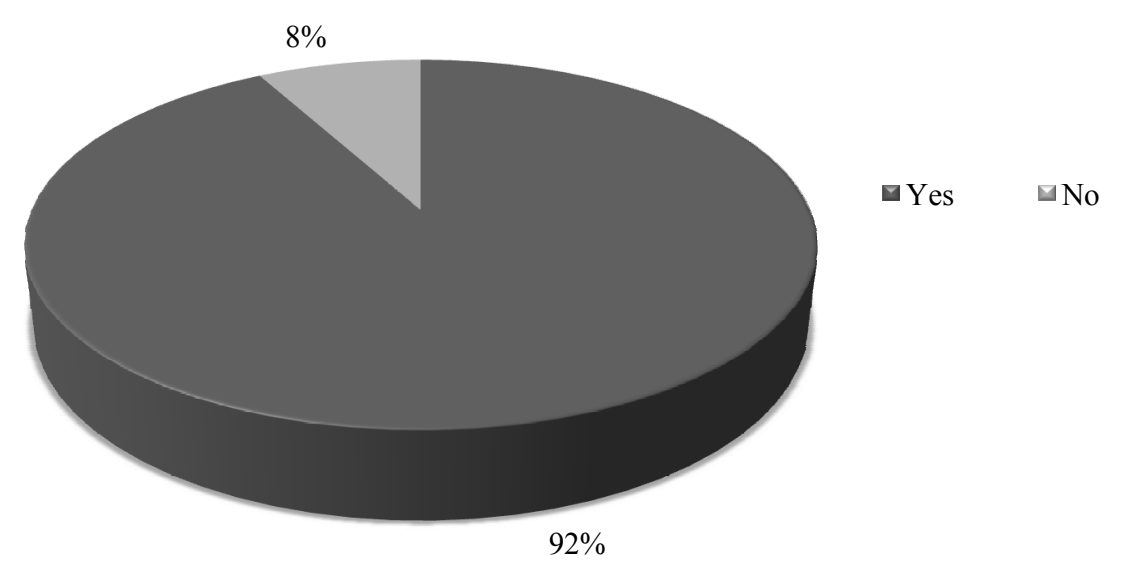

Figure 2. Children visit to school and local library.

\section{The Relation of Book Ownership at Home and Results at School}

In order to assess the impact on school success, an important variable in the research has become the results achieved in the year-end school report in the subjects of Slovak language and literature, mathematics, and English language.

As the great result, we classified the assessment by marks 1 and 2 and $60.24 \%$ of children achieved such result in the last school report (we considered only the last year-end report). $24.10 \%$ of children had an average result. We classified marks 4 and 5 as below average result achieved by the smallest percentage of children $(15.66 \%)$.

The first question for parents we tried to find what range constituted their family library. We divided the range of books for parents into six categories. Most parents (33.73\%) stated that they had at home 21-50 books. $25.30 \%$ of families had up to 100 books, $21.69 \%$ up to 20 books, $10.84 \%$ up to 200 books, $4.82 \%$ up to 300 books, and only $3.61 \%$ of parents had more than 300 books.

Compared with the results of Lukšík research (2012), we came to relatively similar results, $25.8 \%$ of households owned 50 books in the parent library, $19.4 \%$ of families had up to 100 books, $9 \%$ up to 200 books, and $10.8 \%$ more than 200 books. Less than $35 \%$ of families stated that they did not have their own library.

Since we tried to find the level of education of parents in next question, we compared whether the level of education of parents affected the number of books in the family library. The largest group consisted of parents with completed secondary education with graduation (51.81\%), followed immediately by parents with elementary and secondary special education without graduation $(36.14 \%)$, and $12.05 \%$ were parents with a university education.

We can claim from the comparison of the range of books to the level of education of parents that: There were represented all categories of the range of books for parents with lower education, while $46.67 \%$ of parents stated that they had up to 20 books at home. Cabanová et al. (2010) state in the research implemented at Liptov that up to $72.4 \%$ of parents having books in the range of 20 to 100 had more than 300 books at home, similarly to research in 2014 , only $3.6 \%$ have more than 300 books at home. 


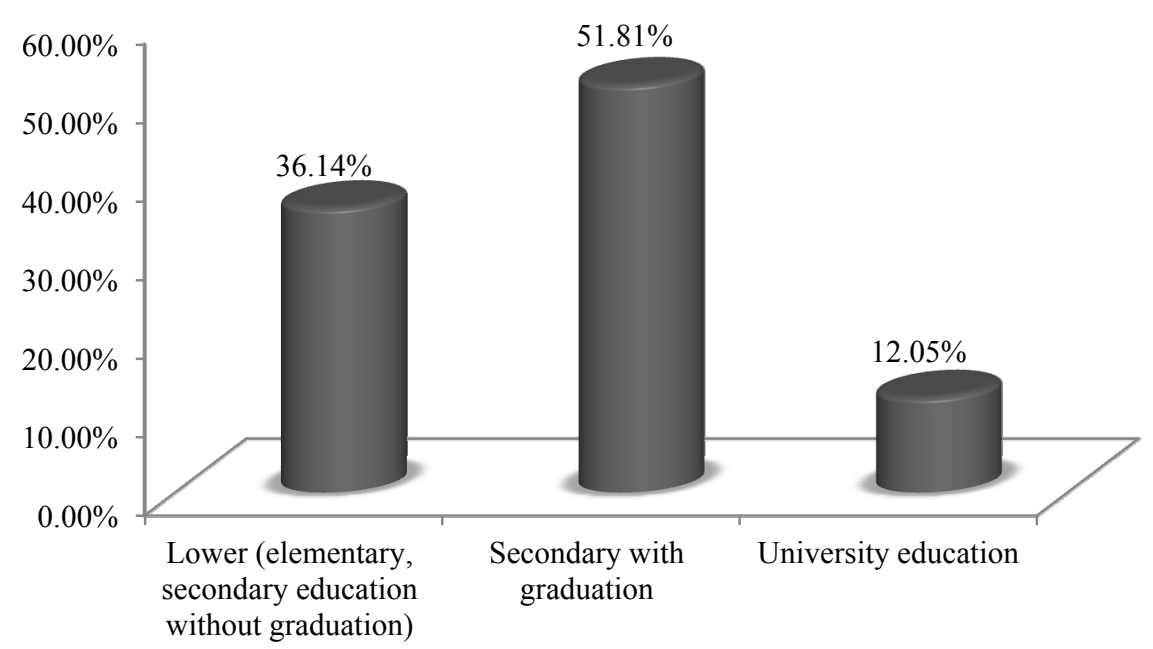

Figure 3. Distribution of parents according to level of education.

The parents with the level of university education were the least so we cannot claim that they had the greatest range of books. 30\% of parents at most stated that they had the range of books 101-200 and surprisingly less than $10 \%$ of university students owned up to 20 books. The university educated parents stated the range of up to 200 books in family library in research in 2007 (Lukšík, 2012), representing 64.3\% of respondents. $4 \%$ of parents had up to 20 books at home and $23.5 \%$ of respondents owned more than 300 books.

Table 1

Ownership of Books in Relation to the Level of Educational of Parents in the Survey in 2014

\begin{tabular}{|c|c|c|c|c|c|c|}
\hline & \multicolumn{2}{|c|}{ Lower } & \multicolumn{2}{|c|}{ Secondary } & \multicolumn{2}{|c|}{ University } \\
\hline & Number & $\%$ & Number & $\%$ & Number & $\%$ \\
\hline $0-20$ & 14 & 46.67 & 3 & 6.98 & 1 & 10 \\
\hline $21-50$ & 11 & 36.67 & 17 & 39.53 & 0 & 0 \\
\hline $51-100$ & 2 & 6.67 & 17 & 39.53 & 2 & 20 \\
\hline $101-200$ & 1 & 3.33 & 5 & 11.63 & 3 & 30 \\
\hline 201-300 & 1 & 3.33 & 1 & 2.33 & 2 & 20 \\
\hline More than 300 & 1 & 3.33 & 0 & 0 & 2 & 20 \\
\hline
\end{tabular}

In addition to the range of libraries in the family, we examined the specialization of books and then the individual genres. The families, in which the proportion of professional books and fiction was about the same, formed the largest percentage (36\%). The smallest percentage of the books exclusively included professional publications which $7 \%$ of families stated.

After analysing the structure of the parent library, we found that the largest percentage $(22.8 \%)$ of all genres constituted geographical maps and atlases. Literature of the 20th century-entertaining and relaxing occurred in $15.6 \%$ of family libraries and fiction of the 20th century, which constituted $14 \%$, is at the third place. Compared with the research in 2010 (Cabanová et al., 2010), the order of the structure of parent library is the same. Differences are visible only in percentages, while our research was implemented in a smaller sample of respondents. 


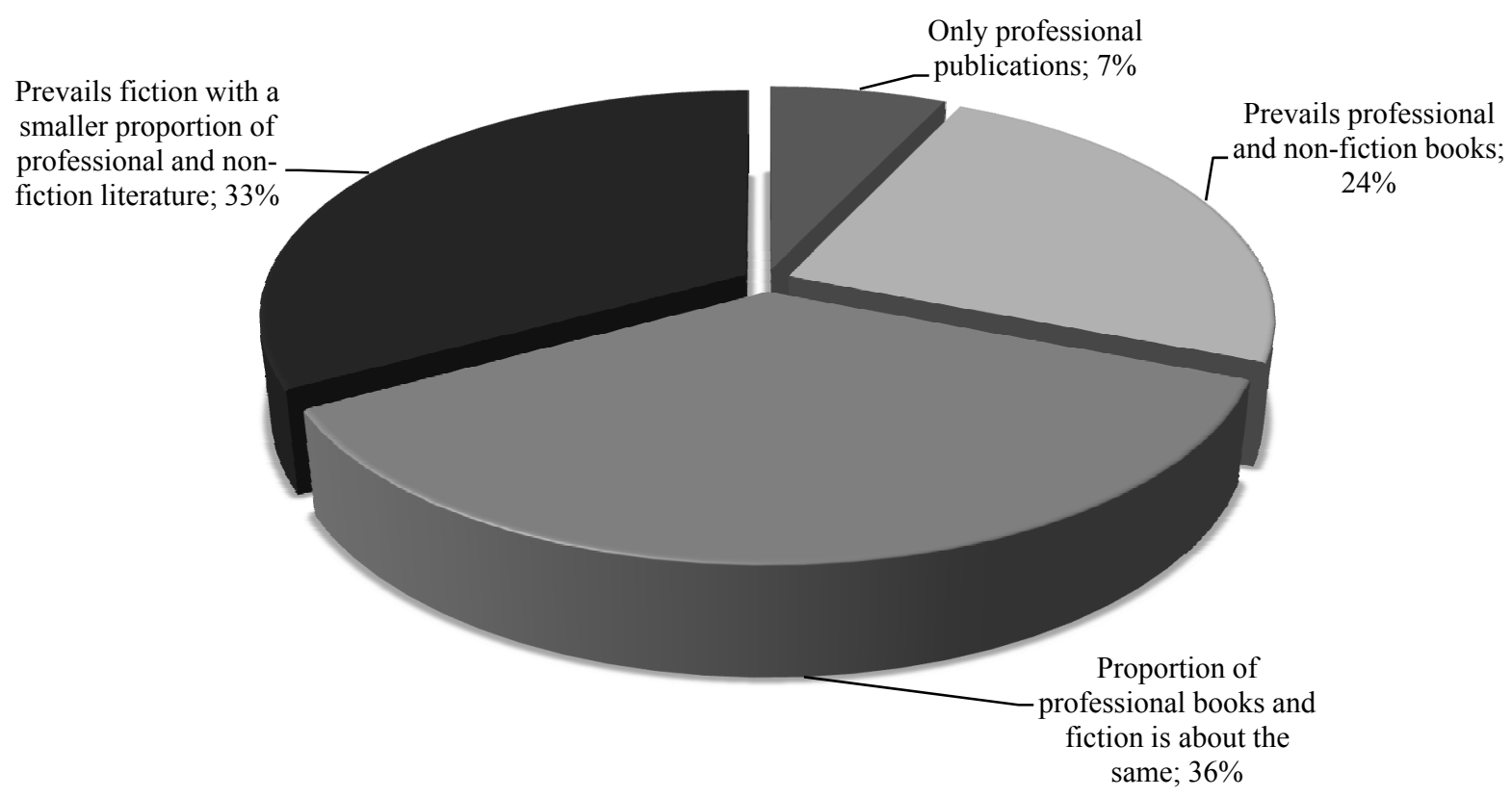

Figure 4. Proportion of families in terms of book specialization.

Table 2

Representation of Genres in the Parent Library

\begin{tabular}{lcc}
\hline Genres & Number & $\%$ \\
\hline Ancient literature and ancient myths & 14 & 5.6 \\
Medieval fiction & 17 & 6.8 \\
Works from the period of humanism and the renaissance & 7 & 2.8 \\
Works written in the 17th, 18th, and 19th century & 13.2 \\
Fiction of the 20th century & 35 & 14 \\
Literature of the 20th century -entertaining and relaxing & 39 & 15.6 \\
Art literature & 15 & 6 \\
Geographical maps, atlases & 57 & 22.8 \\
Literature of humanities and social sciences (philosophical, psychological, ethnographic, historical, etc.) & 15 & 6 \\
Literature in technical fields (engineering, engineering, construction, information, etc.) & 11 & 4.4 \\
Medical and biological literature & 27 & 10.8 \\
\hline
\end{tabular}

Based on the results of book specializations in the parent library, we tried to find what specialization of books prevailed considering the level of education of parents. We can find only professional publications in parents with university education (83.33\%) and secondary education with graduation $(16.67 \%)$. The predominance of professional and popular science books can be found at all levels of education, while $65 \%$ at secondary education with graduation. The predominance of fiction is considerable for parents with lower education, representing $66.67 \%$ of the total number. On the contrary, none of the parents with university education stated the predominance of fiction in their library.

We can claim that not only the number of books but also the frequency stimulate to better results in school. The largest percentage of children (56\%) with excellent result reads books several times a week. $20 \%$ of children with an excellent result read books more times per month. Only $2 \%$ of children with an excellent result do not read books at all. $38.46 \%$ of all children who have the result below average do not read books at all, and 
the same percentage of children read a couple of times a year. Table 2 shows the frequency of reading books compared to the result achieved.

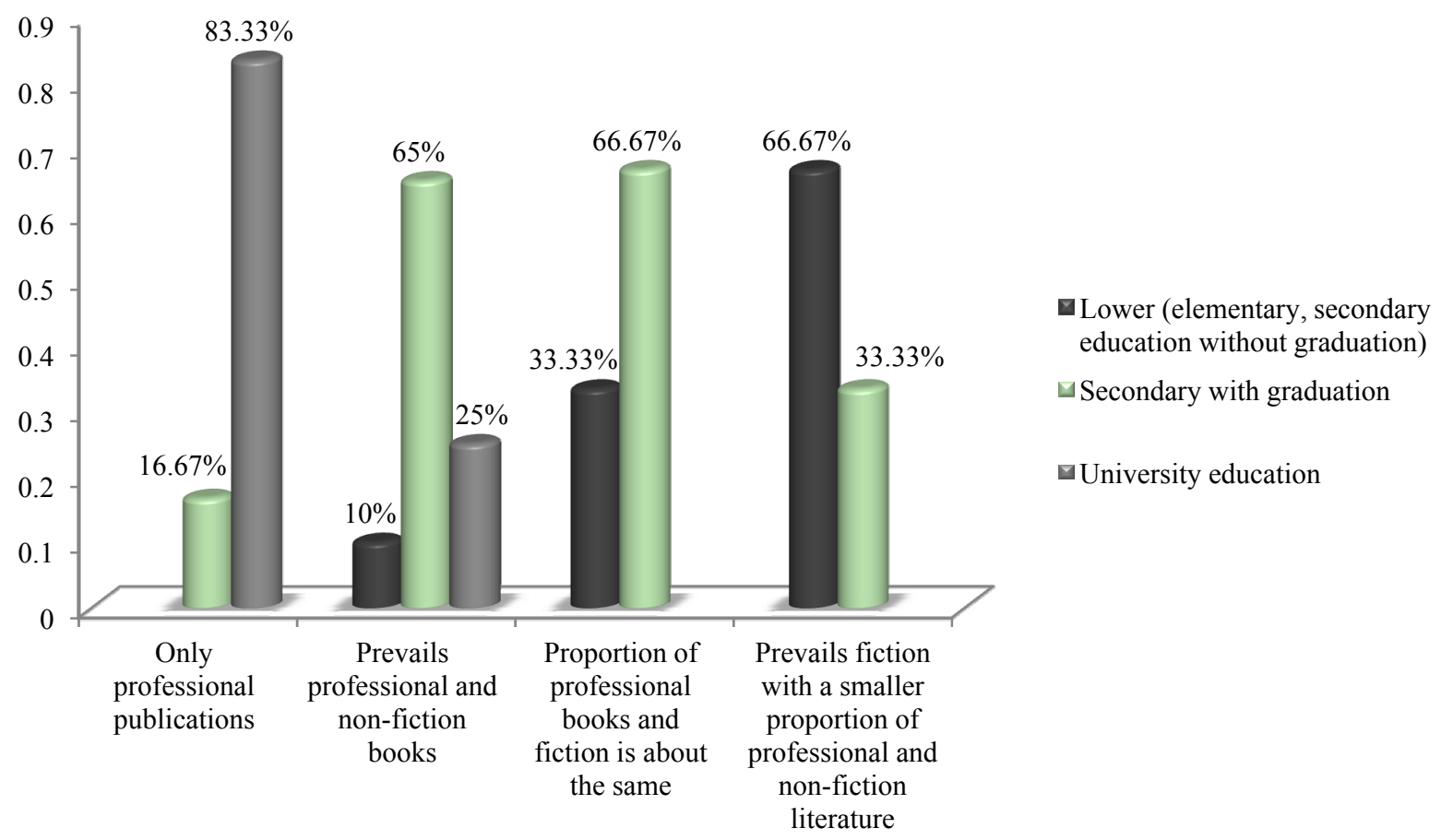

Figure 5. Specialization of books in relation to the level of educational.

Table 2

Frequency of Children Reading Books in Relation to the Results Achieved

\begin{tabular}{|c|c|c|c|c|c|c|}
\hline & \multicolumn{2}{|c|}{ Excellent } & \multicolumn{2}{|c|}{ Average } & \multicolumn{2}{|c|}{ Below average } \\
\hline & Number & $\%$ & Number & $\%$ & Number & $\%$ \\
\hline More times a week & 28 & 56 & 2 & 10 & 0 & 0 \\
\hline Once a week & 2 & 4 & 1 & 5 & 0 & 0 \\
\hline More times a month & 10 & 20 & 4 & 20 & 0 & 0 \\
\hline Once a month & 4 & 8 & 4 & 20 & 1 & 7.69 \\
\hline Several times a year & 4 & 8 & 1 & 5 & 5 & 38.46 \\
\hline Once a year & 1 & 2 & 3 & 15 & 2 & 15.38 \\
\hline Do not read books & 1 & 2 & 3 & 15 & 5 & 38.46 \\
\hline
\end{tabular}

Next, we compared the relation between the range of parental library and school success of children (see Table 3). $40 \%$ of children in the range of 51 to 100 books in the parent library achieved excellent result. We have not recorded an excellent result in the least number of books. The average result occurred in the range up to 100 books, while $60 \%$ of children had such a result in the range of 21 to 50 books. Below average result was significantly demonstrated in children whose parents had the least books at home. $84.62 \%$ of the children had below average result where the least parental library.

When examining what influences or affects school success, we tried to find the relation between the education of parents achieved and the success of children in school (see Table 4). We can find a considerable dependence between school success of children and the education of parents. $80 \%$ of children whose parents 
had secondary education with graduation had an excellent result, $16 \%$ of children of university education parents, and only $4 \%$ of children of parents with lower education. $80 \%$ of children with an average result had parents with lower education. Below average result was fundamentally not demonstrated in children whose parents had a university education compared with the parents with lower education where up to $92.31 \%$ of children had below average result.

Table 3

The Range of Parental Library in Relation to Children Results Achieved in the Survey of 2014

\begin{tabular}{|c|c|c|c|c|c|c|}
\hline & \multicolumn{2}{|c|}{ Excellent } & \multicolumn{2}{|c|}{ Average } & \multicolumn{2}{|c|}{ Below average } \\
\hline & Number & $\%$ & Number & $\%$ & Number & $\%$ \\
\hline $0-20$ & 0 & 0 & 7 & 35 & 11 & 84.62 \\
\hline $21-50$ & 14 & 28 & 12 & 60 & 2 & 15.38 \\
\hline $51-100$ & 20 & 40 & 1 & 5 & 0 & 0 \\
\hline $101-200$ & 9 & 18 & 0 & 0 & 0 & 0 \\
\hline $201-300$ & 4 & 8 & 0 & 0 & 0 & 0 \\
\hline More than 300 & 3 & 6 & 0 & 0 & 0 & 0 \\
\hline
\end{tabular}

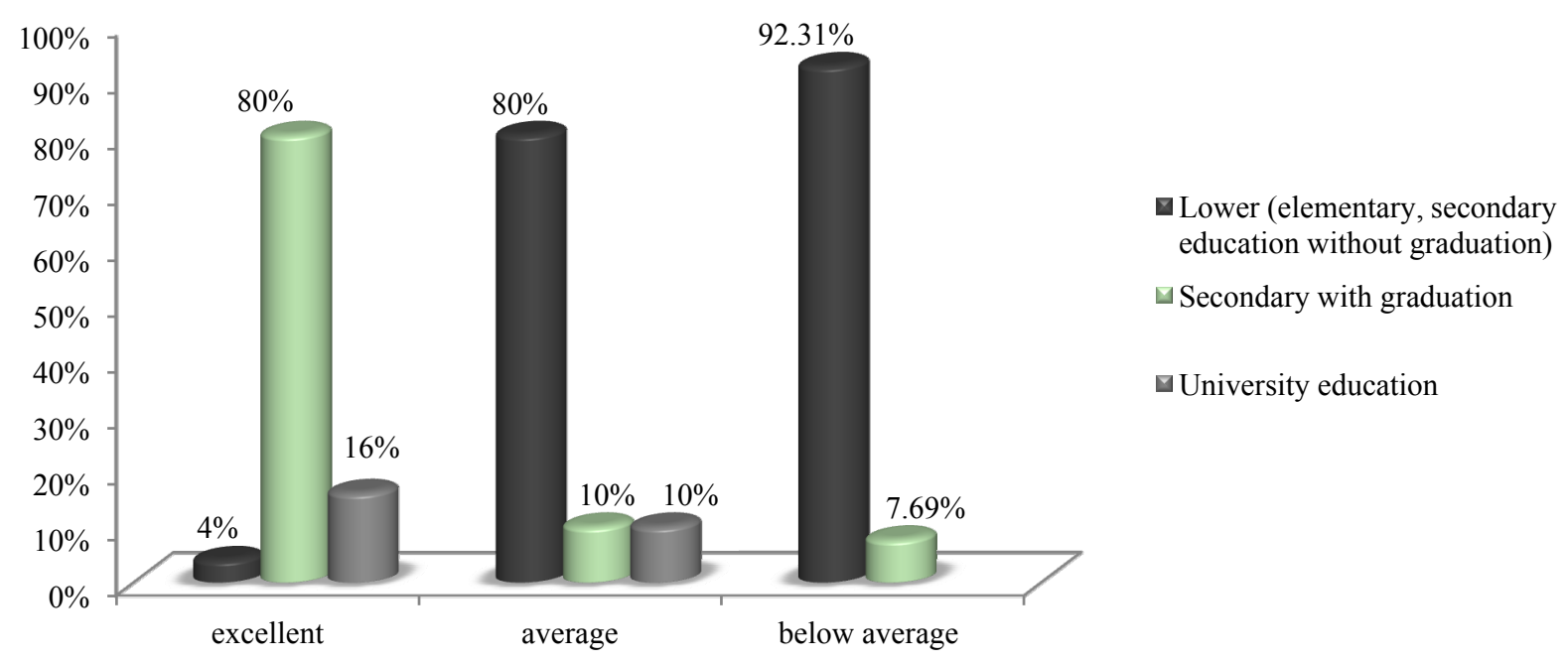

Figure 6. The result of children achieved in relation to the level of education of parents.

\section{Conclusion}

When comparing material conditions of families living in villages and towns, we did not find significant differences in the research focused on the analysis of material and cultural conditions of families. However, we found significant class differences that a book becomes a luxury thing in certain social classes which is caused by the worsening economic situation in many families (Cabanová, 2004). We can find rather small libraries up to 50 books in the majority of surveyed families. Although we know that interest in books is currently decreasing, it is pleasing that considering our research in a given sample of respondents more than half of the children like reading books. A family should be the first place where we meet with the book at very early age. In addition to the school where the child is in constant contact with books, we showed that mother and family members were the ones who caught the attention of children to read books. 


\section{References}

Cabanová, V. (2004). Formovanie vzt’ahu ku knihe v predškolskom období. Rodina A Škola, 52(3), 12.

Cabanová, V. et al. (2010). Rodina a rodinná výchova ako faktor rozvoja osobnosti (p. 83). Žilina: EDIS Publishing, University of Žilina.

Gabrišová, E. (2014). Kultúra rodiny a jej prejavy v škole. FHV ŽUŽ (final thesis).

Katrňák, T. (2004). Odsouzeni k manuální práci (p. 189). Praha: Slon.

Leláková, E., \& Bačová, B. (2014). Development and innovation of curriculum in foreign language. In Proceedings of INTED 2014: The 8th International Technology, Education and Development Conference, pp. 0163-0169, Valencia, Spain. IATED Academy, CD-ROM.

Lukšík, I. A. Kol. (2012). Kultúra škôl a výchovných zariadení (p. 209). Bratislava: Comenius University in Bratislava.

Makarenko, A. S. (1947). O výchově dětí v rodině (p. 111). Praha: Svoboda.

Průcha, J. (2004). Interkulturni psychologie: Sociopsychologické zkoumání kultur, etnik, ras a národů (p. 199). Praha: Portál.

Šmelová, E. (2004). Kniha v rodině předškoláka (online). Retrieved from http://www.rodina.cz/clanek3877.htm 